\section{DOE chops funding for high-energy physics}

\section{- Panel mulls distributing a 10 per cent cut} - Fate of Main Injector at Fermilab uncertain

\section{Washington}

IT seems that no area of physical research will be immune from the forced cuts in the research budget of the Department of Energy (DOE). Last week William Happer, director of DOE's office of energy research, met with the High-Energy Physics Advisory Panel (HEPAP) and asked them to recommend how to allocate a 1993 budget that will be 10 per cent less, in real terms, than that of fiscal year 1992. Previously, Happer had met with advisory committees for fusion research and nuclear science and given them basically the same chore (see Nature 353, 372; 3 October $1991 \& 783 ; 31$ October 1991).

Unlike the fusion and nuclear science communities, each of which was forced to cancel a major project, the high-energy physicists on the panel hope to spread the pain among all their various programmes and avoid shutting anything down completely. "Everybody will suffer at some level," said HEPAP chairman Stanley Wojcicki of Stanford University.

In a letter that should be completed by the end of this week, HEPAP will offer a Happer a list of priorities in high-energy physics for use as a guide in distributing the cuts, Wojcicki said. The top two priorities are to keep university programmes healthy and to maintain research at Fermilab, the major US particle accelerator. It is essential to protect the university programmes, he said, because they have been squeezed severely over the past decade and more cuts could affect the training of future scientists. Fermilab deserves top priority, Wojcicki said, because "it has the highest discovery potential" among NUCLEAR WEAPONS

\section{Tritium 'peace Washington}

BY scavenging tritium from the nuclear warheads it has recently agreed to destroy, the United States will be able obtain enough of the element to fill defence and research needs without building a new production reactor for at least two years, the US Department of Energy (DOE) announced last week. This 'peace dividend' of tritium from old weapons is a windfall for DOE, which had been planning to go ahead with a new tritium-producing reactor at either the Savannah River Laboratory or the Hanford Nuclear Reservation. Now plans for the reactor can be considered along with DOE's reorganization of the US nuclear weapons complex, a process that high-energy physics programmes.

The most controversial question facing HEPAP is what to do about the planned Main Injector at Fermilab. Already, the $\$ 50$ million planned to begin construction on the Main Injector has been moved from the 1992 to the 1993 budget, and HEPAP could not agree on whether it should be pushed back even further. The panel is likely to recommend keeping the Main Injector construction funds in the 1993 budget, Wojcicki said, but with the intention of transferring them to other projects if necessary. It would make no sense to start construction in 1993 if funds were going to dry up in the following years, he noted, and six months from now, the highenergy physics budgets after 1993 will be easier to gauge.

The one high-energy physics project that remains sacrosanct is the Superconducting Super Collider (SSC), but that could change. DOE has always promised that building the SSC, which is funded as a separate item from other energy department research, would not hurt funding of other research, and the current cuts in DOE research budgets are giving SSC opponents ammunition in their fight against the \$8,250-million project. Even George Brown, the chairman of the House Science, Space and Technology Committee, is concerned. In a letter sent in late October to energy secretary James Watkins, he wrote, "When the SSC was proposed by the Administration, Congress was assured that it would not be funded at the expense of ongoing science and research programs. This is obviously no longer true."

Robert Pool

\section{dividend'}

is not expected to be finished until 1993.

With a planned reduction of more than 3,000 weapons, requiring an average of up to 4 grams of tritium each, current US disarmament proposals are expected to free up as much as $10 \mathrm{~kg}$ of tritium. DOE officials say that should be plenty for the next few years; additional disarmament negotiations are likely to drastically reduce the number of new weapons needed, and research consumes less than 200 grams of tritium per year. Although safety concerns have currently halted all US reactors that can produce tritium, DOE also plans to restart the ' $\mathrm{K}$ ' reactor at its Savannah River site by the end of the year.

Christopher Anderson
Hunger strike at volcanology institute

A ONE-WEEK hunger strike has won an apparent victory for ten Soviet geologists protesting a proposed move that would have put their fledgling volcanology institute under the direction of a feared and "autocratic" administrator.

The staff members of the newly formed Institute of Volcanic Geology and Geochemistry (IVGG) in PetropavlovskKamchatsky, Russia, began the strike last month to avoid being put under the command of Sergei Fedotov, who has run the Institute of Volcanology for the past 20 years. In an open letter that has been distributed on computer networks to scientists outside the Soviet Union, the striking researchers wrote, "Imposing of co-authorship, hampering of academic career[s], blocking of trips abroad, and ... firing of dissidents are typical [of Fedotov's] style of leadership."

After years of complaints about Fedotov, the Soviet Academy of Sciences allowed researchers at the Institute of Volcanology the option of moving to a new institute, the IVGG. Forty per cent took the offer, although they have so far been given little funding or access to research facilities.

But last month Georgy Yelyakov, head of the Far East division of the academy, appointed Fedotov to run a commission overseeing the separation of the IVGG from the volcanology institute. As a result of this decision, the strikers wrote, "in less than half a year, Prof. Fedotov has become our immediate supervisor again. The inevitable effect of these decisions will definitely be the end of our last capabilities to do research work."

They ended their protest last week when Yelyakov sent them a cable promising to halt the appointment of Fedotov until a committee could review the situation.

In 1987, an extraordinary investigative article in Moscow News described several cases in which Fedotov demoted outspoken critics at the volcanology institute. The article describes the aftermath of a $\mathbf{1 9 8 4}$ letter in which 12 institute researchers wrote to the president of the Soviet academy complaining about Fedotov. Three subsequently had their salaries cut, one lost a laboratory, two were denied approval for their research projects and left the institute, and three were dismissed.

Although the strike is over, US researchers who followed the situation say the Soviet scientists are not relaxing. "They've received assurances like this in the past, so they're skeptical," says Thomas Miller, of the US Geologic Survey's Alaska Volcano Observatory. With a letter to US geologists, Miller and fellow researcher $\mathrm{C}$. Dan Miller are hoping to start a fax and telegram campaign in support of the embattled geologists. Christopher Anderson 